\title{
ENRICHING ABSORPTIVE CAPACITY THROUGH SOCIAL INTERACTION
}

\section{Jasper J. Hotho, Florian Becker-Ritterspach ${ }^{1}$ and Ayse Saka-Helmhout ${ }^{2}$}

Department of Strategic Management and Globalization, Copenhagen Business School, Kilevej 14A 2, 2000 Frederiksberg, Denmark,

${ }^{1}$ Department of Global Economics and Management, Faculty of Economics and

Business, University of Groningen, PO Box 800, 9700 AV Groningen, The Netherlands, and

${ }^{2}$ School of Management, University of Surrey, Guildford, Surrey GU2 7XH, UK

Email: jjh.smg@cbs.dk; florian.br@gmx.de; a.saka-helmhout@surrey.ac.uk 


\begin{abstract}
Absorptive capacity is frequently highlighted as a key determinant of knowledge transfer within MNEs. But how individual behaviour translates into absorptive capacity at the subsidiary level, and exactly how this is contingent on subsidiaries' social context, remains under-addressed. This not only limits our understanding of the relationship between individual and organizational level absorptive capacity, it also hampers further research on potentially relevant managerial and organizational antecedents, and limits the implications we can draw for practitioners that seek to increase their organization's capacity to put new knowledge to use. To address this shortcoming we conduct an in-depth comparative case study of a headquarters-initiated knowledge transfer initiative at two subsidiaries of the same MNE. The findings demonstrate that social interaction is a prerequisite for subsidiary absorptive capacity as it enables employees to participate in the transformation of new knowledge to the local context and the development of local applications. Second, the findings illustrate how organizational conditions at the subsidiary level can impact subsidiary absorptive capacity by enabling or constraining local interaction patterns. These insights contribute to the absorptive capacity literature by demonstrating the scale and scope of social interaction as a key link between individual- and organizational-level absorptive capacity.
\end{abstract}

Key words: absorptive capacity; social interaction; subsidiary learning 


\section{INTRODUCTION}

The ability to generate and transfer knowledge is frequently highlighted as a key capability of the multinational enterprise (MNE) (e.g., Kogut and Zander, 1993; Grant, 1996). It should therefore come as no surprise that intra-MNE knowledge transfer has emerged as one of the main research topics within research on MNEs (Foss and Pedersen, 2004; Pisani, 2009). Yet while the dominant conceptualization of intra-MNE knowledge transfer, the sender-receiver perspective (Carlile, 2004; Noorderhaven and Harzing, 2009), has generated valuable research on for instance the relation between sender and receiver and the richness of the transfer channel (e.g., Gupta and Govindarajan, 2000; Almeida and Phene, 2004; Schulz, 2003), it has also diverted attention from the micro-level origins of subsidiary learning. As a result we still know little about, for instance, the organizational antecedents that enable or constrain subsidiary learning and how subsidiary learning relates to the behaviour of individual actors (Foss and Pedersen, 2004).

Making better use of the absorptive capacity construct-the combination of a receiving unit's ability and motivation to recognize, assimilate and apply new knowledge (Cohen and Levinthal, 1990; Minbaeva et al., 2003)—may help shed light on the foundations of subsidiary learning. In fact, absorptive capacity of the receiving unit is already frequently highlighted as a key determinant of knowledge transfer within MNEs (e.g., Gupta and Govindarajan, 2000; Minbaeva et al., 2003) and subsidiaries’ innovativeness and profitability (e.g., Tsai, 2001; Phene and Almeida, 2008). However, the explanatory power of absorptive capacity itself is limited by insufficient attention to the link between the individual and organizational level. What remains particularly unclear is how individual behaviour translates to absorptive capacity of the organizational unit. As a result, our understanding of how new 
knowledge is assimilated internally and the role of individual actors and organizational conditions remains incomplete.

To better understand the micro-level origins of absorptive capacity, we conduct an indepth comparative case study of two subsidiaries in the context of a centrally initiated knowledge transfer within the same MNE. The two subsidiaries are very similar, yet demonstrate differences in their capability to learn and to sustain the transfer initiative. While the German subsidiary displays extensive learning across organizational levels, the British subsidiary displays only limited learning and the transfer initiative is not sustained locally.

We find that the difference in the subsidiaries' capacity to absorb and apply knowledge is strongly linked to differences in social interaction patterns, such as differences in social cohesion, the extent (or scale) of interaction and the diversity (or scope) of interacting employees. In particular, the findings illustrate that social interaction is crucial in enabling individual actors with diverse knowledge to participate in the transformation of knowledge to the local context. This suggests that social interaction is not merely facilitative of organizational-level absorptive capacity (cf. Zahra and George, 2002; Todorova and Durisin, 2007) but a prerequisite to it: It performs the key role of linking individual absorptive capacity to that of the organizational unit. This complements work that highlights the role of interaction between sender and receiver (e.g., Noorderhaven and Harzing, 2009; Tsai and Ghoshal, 1998; Yli-Renko, Autio and Sapienza, 2001), by illustrating that variation in intra-unit interaction patterns may be similarly important for understanding learning and innovation outcomes. As MNE dyads often display high relative absorptive capacity due to shared dominant logics and structures (Lane and Lubatkin, 1998), variation in intra-unit social interaction patterns may be particularly relevant in explaining differences in learning between MNE units. 
The findings also suggest how the ability and willingness of individuals to participate in knowledge transformation relates to organizational conditions, such as incentive systems, leadership style and structural demarcations. Such conditions impact subsidiary success in the integration of new knowledge, and whether subsidiary learning efforts are sustained locally, by facilitating or constraining social interaction, and hence actors' involvement in the transformation of new knowledge. This extends recent work by Gooderham, Minbaeva and Pedersen (2011), who suggest that the effect of various governance mechanisms on knowledge transfer is mediated by their impact on social structure, and contributes to calls for a deeper understanding of how organizational conditions impact organizational knowledge processes (Foss and Pedersen, 2004; Foss, 2007).

The remainder of this paper is organized as follows: In the following section we discuss the literature on knowledge transfer and absorptive capacity. We then present the research methodology and introduce our research sites. The empirical findings-differences in learning patterns within the same MNE-are presented in section 4. In section 5 we discuss our findings and develop a set of propositions. In section 6 we present our conclusions and highlight the contribution of the study to the literature on absorptive capacity and MNE knowledge processes.

\section{SUBSIDIARY LEARNING AND ABSORPTIVE CAPACITY}

The dominant conceptualization of knowledge transfer within MNEs is that knowledge flows are promoted or impeded depending on characteristics of the sending unit, the transmission channel, the transfer message, the receiving unit, and the transmission context (Szulanski, 2000). Accordingly, MNE research has particularly furthered our understanding of how intraMNE knowledge flows differ depending on characteristics of, for instance, the sending and 
receiving unit (Gupta and Govindarajan, 2000; Phene and Almeida, 2008; Szulanski, 1996), the knowledge to be transferred (Schulz, 2003; Dhanaraj et al., 2004) and the richness of the transfer channel (Almeida and Phene, 2004; Björkman, Barner-Rasmussen and Li, 2004; Hansen and Løvås, 2004). However, the implicit emphasis on the transfer process has also limited research from focusing on the sub-organizational conditions that affect MNE learning. This limits our understanding of MNE knowledge processes in at least three respects.

First, there is still little understanding of the role of individual actors in MNE knowledge adoption and integration, in particular how their social interaction translates into subsidiary learning. As a result, it is often "hard to link knowledge processes, such as knowledge transfer, to [individual] behavior” (Foss and Pedersen, 2004: 343), which hampers both theory development and the formulation of managerial implications.

Second, MNE knowledge research has mainly explored the impact of social factors in the internal network context. For instance, social relations have been found to both facilitate knowledge flows between MNE units (e.g., Hansen, 1999; Gupta and Govindarajan, 2000; Björkman et al, 2004), such as by increasing awareness of other units’ knowledge stock and knowledge needs (Schulz, 2003), and to affect knowledge sharing between MNE units directly (Noorderhaven and Harzing, 2009). Instead, there is much less work that looks at the role of social interaction within MNE units, and we consequently know relatively little about the extent to which knowledge transfer and adoption is contingent on subsidiaries' social context.

Finally, MNE knowledge research still pays little attention to the changes knowledge inflows and the receiving context undergo when transferred knowledge is integrated (BeckerRitterspach, 2006; Hong and Nguyen 2009). Thus, how received knowledge is translated, 
interpreted, and locally integrated, or the transformative aspect of knowledge transfer, is often ignored.

The argument developed below is that these shortcomings can be addressed both by more fully embracing the concept of absorptive capacity in understanding subsidiary learning, and by extending the concept of absorptive capacity to better understand how behaviour at the micro-level of individual actors translates into differences in learning outcomes at the subsidiary level. Although subsidiaries' absorptive capacity is already recognized as one of the key factors facilitating MNE knowledge transfer (e.g. Gupta and Govindarajan, 2000; Minbaeva et al., 2003), the literature primarily considers absorptive capacity in relation to knowledge acquisition (e.g., Gupta and Govindarajan, 2000). Which and how local conditions facilitate the subsequent transformation and successful application of new knowledge is rarely looked into. Hence, the MNE literature tends to make only partial use of the notion of absorptive capacity.

This, we feel, is a missed opportunity. Absorptive capacity shares a conceptual affinity with organizational learning (Sun and Anderson, 2010) and, as both an antecedent and consequent of organizational learning processes (Lane, Koka and Pathak, 2006), absorptive capacity is well suited to enhancing our understanding of subsidiary learning. In particular, both the construct's attention to local conditions and the transformative nature of knowledge may further our understanding of how local conditions enable or constrain subsidiary learning outcomes. ${ }^{i}$ However, as we explain below we also claim that the notion of absorptive capacity needs to be extended. In particular, what remains under-addressed is how the actions of individual actors translate into absorptive capacity at the organizational level and exactly how this is contingent on the social context. 


\section{Absorptive capacity}

Despite differences in emphasis and more recent refinements (e.g., Zahra and George, 2002; Todorova and Durisin, 2007), the concept of absorptive capacity essentially rests on three components (Cohen and Levinthal, 1989; 1990): Recognizing and acquiring new knowledge, processing new knowledge—-labelled as assimilation and/or transformation—and putting new knowledge into effective use. Organizational units’ absorptive capacity first of all depends on prior knowledge (Cohen and Levinthal, 1990): Related knowledge facilitates the effective communication of new knowledge, while diversity of knowledge stimulates innovative application of new knowledge. Second, organizational units' ability to absorb new knowledge is affected by the interface between knowledge source and receiving unit. Here, similarity between sending and receiving unit facilitates the effective communication of new ideas (Lane and Lubatkin, 1998; Gupta and Govindarajan, 2000), while boundary spanners play the important role of translating and disseminating new information internally (Cohen and Levinthal, 1990).

In addition, absorptive capacity is also linked to local conditions (e.g., Cohen and Levinthal, 1990; Zahra and George, 2002; Jansen, Van den Bosch, and Volberda, 2005). This is because the ability to adopt new knowledge and practices and to put that knowledge into practical use depends not only on knowledge acquisition, but also on how transferred knowledge and practices are assimilated and/or transformed, and subsequently implemented. Here, both social interaction and organizational processes are argued to play a role (Cohen and Levinthal, 1990; Volberda, Foss and Lyles, 2010). Social interaction has been repeatedly linked to the ease with which the different components of absorptive capacity take place (e.g., Zahra and George, 2002; Todorova and Durisin, 2007). And while units’ absorptive capacity is a function of local actors' individual absorptive capacity (Cohen and Levinthal, 1990), it is 
organizational processes that "enable the organization to share, communicate, and transfer individual-level learning to the organizational level” (Lane et al., 2006: 846).

\section{The micro-macro link of absorptive capacity}

Applied to the context of MNEs, the notion of absorptive capacity therefore provides useful leads on how subsidiary-level learning outcomes relate to sub-organizational processes and conditions. However, two related issues also limit the explanatory potential of absorptive capacity in understanding subsidiary learning, namely inattentiveness in empirical studies to the role of social context beyond its impact on knowledge acquisition, and insufficient theoretical discussion of how individual behaviour translates into absorptive capacity of the organizational unit.

While empirical work on absorptive capacity highlights the role of social interaction between sender and receiver (e.g., Dhanaraj et al., 2004; Lane and Lubatkin, 1998; Reagans and McEvily, 2003; Tsai, 2002), attention to the effects of units' internal social context has, with exceptions (e.g., Van den Bosch, Volberda, and De Boer, 1999; Jansen et al., 2005), been much more modest. In addition, researchers have traditionally adopted a relatively narrow view of absorptive capacity as relating to firms' prior knowledge base-often with R\&D intensity as a proxy-in which the organizational processes leading to knowledge acquisition, transformation and application are often overlooked (Lane et al., 2006). As a result, our understanding of how new knowledge is assimilated and the role that individual actors assume in this process remains limited (Volberda et al., 2010).

This relative inattentiveness in empirical research to intra-unit social interaction is reflected in theoretical discussions on what constitutes absorptive capacity. The roots of absorptive capacity are in work on human cognition (e.g., Bower and Hilgard, 1981; Lindsay and Norman, 1977) and, hence, there has been much attention to the role of individual 
capabilities. But how individual behaviour translates into absorptive capacity of the organizational unit is not sufficiently discussed: Although social interaction is recognized as linking individual behaviour to units’ absorptive capacity (Cohen and Levinthal, 1990), in most discussions the relationship between social interaction and absorptive capacity is often sidelined as an antecedent or merely inferred from the notion that absorptive capacity comprises a set of organizational routines (e.g. Zahra and George, 2002; Todorova and Durisin, 2007). Instead, whether and how differences in social interaction translate into organizational-level differences in learning outcomes remains under-addressed, and how and why social interaction patterns may differ is not sufficiently specified. This implies that we still have little knowledge of the micro-level origins of absorptive capacity at the subsidiary level. Therefore, we aim to explore how and why actors' interactions shape absorptive capacity at the organizational level to produce different learning outcomes.

\section{METHODOLOGY}

We strive to achieve this objective through a comparative case study of the centrally initiated introduction of continuous improvement principles at two subsidiaries of a Dutch MNE in the chemical industry. Dutch Chem (a pseudonym)—a Fortune Global 500 company—employs 62,000 people globally and operates in more than 80 countries. We selected two subsidiaries that differ markedly in terms of learning outcomes, although they are very similar in terms of characteristics that are predicted by the knowledge transfer and absorptive capacity literatures to affect learning outcomes (Table 1). The two subsidiaries, which are located in the UK and Germany and belong to the firm's paints division, displayed similar characteristics in terms of transfer content, transfer channel and key characteristics of the sending and receiving unit. In addition, both subsidiaries were similar in size, operated in the same field of business and 
had a comparable knowledge base and motivational disposition. Yet, as illustrated in the following sections, the two subsidiaries differed markedly in terms of learning outcomes. The case studies consisted of both field research—carried out between 2006 and 2007—and desk research. Field research consisted of visits to headquarters and two day-long visits, followed by a week-long participant observation at each subsidiary. Data collection involved conducting semi-structured interviews and collection of documents (see Table 2).

Tables 1 and 2 about here

\section{Empirical definitions}

Drawing on the three core elements of absorptive capacity, we see subsidiary learning as based on organizational members' ability and motivation to acquire, transform and practically apply new knowledge (Minbaeva et al., 2003). In addition, similar to Szulanski’s (1996) concept of 'retentive capacity', we see the success of learning expressed in the transformation and sustained use of new knowledge. Thus, we consider learning outcome as 'extensive' when acquired knowledge is transformed, applied and sustained in new or changed practice. Conversely, we consider learning as 'limited' when acquired knowledge is not transformed, applied and sustained in new or changed practice.

Guiding the case analyses is our interest in the link between the success with which the transferred continuous improvement initiatives were transformed, applied and sustained, and the social interaction patterns at both subsidiaries. In line with Lane et al. (2006)'s view of transformation as relating to the combination of new with existing knowledge, we operationalized 'transformation' as a change in knowledge content resulting from local 
reinterpretations of the continuous improvement principles. Instead, analogous to the view of application as the commercialization of new knowledge (Cohen and Levinthal, 1990; Lane et al., 2006), ‘application' was deemed to have taken place if the introduction of continuous improvement practices resulted in the development of new practices, or in changes in old practices.

Finally, we took social interaction patterns as a function of both the actors involved in learning activities and the relations between these actors. Although social interaction is often considered to facilitate access to and the acquisition of external information (Nahapiet and Ghoshal, 1998; Inkpen and Tsang, 2005; Gupta and Govindarajan, 2000), absorptive capacity also relates to how knowledge is transformed and applied internally. In addition to the level of social cohesion among actors and the strength and persistence of social interaction patterns, which have both been linked with knowledge acquisition (e.g., Reagans and McEvily, 2003; Szulanski, 1996; Tsai and Ghoshal, 1998; Yli-Renko et al., 2001), we therefore also focus on the scope of interaction, or who participates in learning activities and in what role (Adler and Kwon, 2002; Zahra and George, 2002).

\section{Data analysis}

The data analysis followed Eisenhardt (1989, Eisenhardt and Graebner, 2007) in starting with within-case analysis followed by cross-case analysis. This involved first detailed and descriptive 'write-ups' for the two cases. Field notes, transcribed interviews and documents were manually coded according to analytical categories derived from the theoretical discussion (see the Appendix for an illustrative list of codes and statements denoting how these are related). Interviews were decomposed and chunks of coded interview-sections grouped according to our analytical dimensions. The reliability of the findings was enhanced by making explicit the procedures that were followed for data collection. For example, we 
recorded interviews, and collected participants' feedback on transcripts and executive summaries. To further ensure reliability of the data, several data quality checks were performed. For instance, interview data from a particular work group were checked against responses from another group. Similarly, subsidiary and headquarter members' accounts were cross-checked. Recurring themes and categories were identified and coding checks during the coding process ensured agreement among research team members.

The second step consisted of the cross-case comparison, where the objective was to identify patterns of similarities and differences across cases (Ragin, 1987). Following the 'pattern matching logic' (Ragin, 1987; Pauwels and Matthyssens, 2004), the final analytical step of this study involved investigating and exploring whether or not the differences in subsidiary learning could be attributed to associations between the analytical dimension of social interaction. This process was supported by extensive efforts of data display as suggested by Miles and Huberman (1994) (see also the tables in the empirical findings section below). An effort was made to specify associations that were deliberately not explicated in the theoretical framework. Contradictions, matches and newly emerging associations were then fed into propositions presented in the discussion of this work (Eisenhardt, 1989).

\section{EMPIRICAL FINDINGS}

In response to increased competition, in 2003 the European paints division of Dutch Chem initiated a continuous improvement programme labelled Star Trek, which was driven by headquarters and involved the same approach at all sites. Sites were required to work with a consultancy group that focused on improving operational performance through Paretoanalysis. This was combined with the transfer of new knowledge on continuous improvement 
principles from headquarters to the subsidiaries through extensive documentation. The documentation suggested a road map, and a range of systems (such as Kaizen, Six Sigma, and Lean manufacturing) and tools (such as 5S and value stream mapping) that the sites could use to realize continuous improvement. Yet despite many similarities in terms of characteristics related to absorptive capacity—such as age, size, knowledge levels and motivation - the two subsidiaries differed considerably in the transformation and application of the acquired knowledge, and their learning outcome (see Table 3 for an overview).

Table 3 about here

\section{Learning at German Sub}

\section{Knowledge absorption at German Sub}

At the start of the Star Trek initiative German Sub was asked to reduce its production costs by half. Although this came as a surprise to the German management, the looming closure of the site proved a strong motivation to acquire the transferred knowledge. Similar to other sites, German Sub received key performance indicators, a road map and a range of systems and tools to be used to realize continuous improvement. Although the site was also required to involve an external consultancy firm in the initiation stage, management ended the consultancy firm's involvement in the implementation stage as the "sustainability [of the consultancy's solutions] went away" as they "went from one project to the other" (plant director).

At German Sub, transformation of the knowledge content occurred in two ways. First, it manifested in a strong focus on the behavioural aspects of the Star Trek initiative, 
with particular emphasis on changing "people's behaviour and in creating a culture environment” (plant director). New behavioural guidelines were developed to facilitate continuous improvement behaviour in daily operations (Master Plan Continuous Improvement Germany). The resulting "Production role model Cologne”, called for employee openness for change, emphasized their responsibility to contribute to improvements, and highlighted managers' responsibility to create a work environment that facilitates employee involvement. In addition, Star Trek was reframed and translated into various local visions and slogans, as it was argued that "you have to get people's attention and you cannot get their attention with something they don't grasp or associate with” (factory manager). "Star Trek” was substituted by the strategic vision “Cologne is a leading production site for paint" with the guiding slogan "Cologne: Impossible is nothing”. At the level of operators, it translated into the slogan "We Colognians hand in hand" and featured the image of the dome of Cologne.

Second, transformation of the original content also manifested in the partial selection and adaptation of the systems and tools suggested in the Star Trek documentation. Managers at German Sub found it neither feasible nor necessary to adopt all systems and tools, such as Lean, Six Sigma, TPM, and TQM. These were considered to share "the notion to approach things in a structured way" (factory manager), and were seen as "a reference and way of thinking to move forward” (Masterplan continuous improvement Germany) rather than as systems to be meticulously implemented (factory manager). Moreover, selected tools, such as 5S, were reinterpreted. A Master craftsman explained:

"We call it S4S, Standards for Safety. $5 S$ is the standard understanding which was originally introduced by Toyota and zealously followed since, all the way down to organizing your desk and defining a position for your pen. I am a big fan of imitation. Now, if someone had a good idea and we try to take that on board one on 
one, this is not possible. Because each plant is different. I can get ideas from somewhere else, but I then have to see what fits my system best."

Application of the new behavioural guidelines and adapted systems was reflected in new improvement practices. For example, improvement practices changed from a "bureaucratic and cumbersome" suggestion scheme (operator), to sustained continuous improvement practices manifesting in "simple orders for the workshop" (group advisor). Specific applications included changed filling processes for acticides, filter renewal, eye shower installations, piping to reduce yeast and the development of a system to track the service level. Not only did these improvements outlast the end of the Star Trek initiative at the subsidiary, but the implementation of continuous improvement principles also proved sustainable after the initiative had died down at corporate headquarters. Thus, the German subsidiary not only engaged in extensive transformation of the transfer knowledge, but was also able to apply this knowledge in the form of changed and sustained local practices.

\section{Social interaction at German Sub}

The extensive transformation and application of Star Trek principles at the German subsidiary crucially rested on the participation of a wide scope of internal actors, in terms of functional and hierarchical diversity, and large-scale cross-functional and -hierarchical integration and interaction.

First, transformation of the Star Trek initiative involved a wide scope of participating actors with different functional backgrounds from across the hierarchical range. While top management transformed the Star Trek principles into a strategic vision, middle management and, in particular, first-line supervisors crucially transformed the vision into behavioural guidelines and day-to-day improvements. Operators were asked to participate in transforming 
the vision into behavioural guidelines and continuous improvement routines, as it was widely recognized that they "know three times more than the stupid manager knows" (factory manager). In the words of one group advisor, when it comes to "machine knowledge and understanding the problems, there the man in the line knows best and one has to appreciate that”. Appreciation of operator participation was reflected in the perception where improvements originated from: "A bit comes from the leader-level in filling and in production, but for the most part it comes from the people working on the machines day-in day out and say: 'Listen, I have a problem here can’t we do this or that'.” (factory manager). Involvement of the local work council also proved instrumental, as it secured the participation of operators while protecting their interests.

Transformation and application of the continuous improvement principles also rested on strong social cohesion. The cross-hierarchical cohesion at the German site stemmed to a large degree from the low professional distance between middle management and supervisors and to operators on the shop floor, owing to their own technical or vocational training and careers. In addition, operators, supervisors and maintenance staff worked in close physical proximity and under the same managerial authority, which promoted social cohesion among the different occupational groups. Moreover, there were few demarcations between the members of different shifts as personnel shifted back and forth on a continuous basis. Finally, the relationship between management and the work council, described by management as a constructive relationship "of give and take” (factory manager), added to social cohesion and to an increase in mutual trust between management and labour.

Furthermore, the scale of social interaction related to improvement activity was not spatially or temporally confined. After the initial failure to sustain the improvement projects initiated by the consultancy firm, improvement activities were deliberately not confined to any particular group or project. Instead, efforts were made to realize improvement activity 
throughout the organization, and at the time of research a continuous improvement culture had materialized in which extensive cross-functional and -hierarchical interaction had become part of daily work. For instance, employees had become more aware of whether problems encountered in other departments were "comparable or even identical to those [they] have, and [whether they could] try to solve these problems with a common approach" (group advisor), which increased interaction with other functional departments. Similarly, when operators encountered production problems, they would now "simply walk into the production supervisors' office" (operator) who would then personally contact the maintenance supervisor.

\section{Organizational conditions at German Sub}

The comprehensive social interaction pattern at German Sub was facilitated by organizational conditions that enabled and encouraged the participation of employees in transforming the Star Trek principles. These conditions included a participatory leadership style, limited structural demarcations and a changed incentive system (Table 4).

First, the site manager of the German subsidiary was a proponent of participatory leadership. This had led to the parting with the external consultancy which "did not care about people” (plant director), and several middle managers who were seen to obstruct participatory leadership had been replaced. A vital part of the leadership style consisted of open communication. It was openly communicated that Star Trek and the improvements that potentially resulted from it could lead to job losses. At the same time, redundancies, contrary to what Star Trek documents suggested, were seen as a last resort. This in turn secured trust, which increased social cohesion and the willingness within the workforce to further participate in improvement processes. As one interviewee put it: “The whole thing [...] builds 
on trust, no matter whether you communicate something nice or bad. Employees have to, or not just employees, the whole team, has to have trust in each other” (group advisor).

Second, participatory leadership was supported by limited structural demarcations. For example, vertical demarcations were reduced by devolving responsibility from supervisors to groups of operators headed by a group speaker. While the role of the supervisors had shifted to a more advisory role, the remaining supervisors still formed an important link between workers and middle management. Regarding horizontal demarcations, the integration of the maintenance unit into production proved crucial. Before, production groups had been strictly separated into departments - there had been "a wall between different departments” (operator)—, and the head of maintenance controlled and approved all process changes. Integration of the two units not only reduced this hierarchy but also “internalized the interface” between maintenance and production (group advisor), which facilitated cross-functional interaction. Overall, the structural changes reduced organizational demarcations. This facilitated a climate for social interaction and cohesion across functions, departments and hierarchical levels.

On top of the structural changes and participatory leadership style, social interaction among different occupational groups in the newly composed production department was also facilitated by the introduction of a common "group-bonus system" (works council). The group bonus system enhanced social interaction as "fitters react to any gout now” (operator), and encouraged “people [to] think and cooperate across shifts and departments”, which signalled increased social interaction and cohesion.

Table 4 about here 


\section{Learning at UK Sub}

\section{Knowledge absorption at UK Sub}

Confronted with decreased production volumes and the threat of closure, UK Sub was motivated by similar incentives as German Sub to acquire and adopt the Star Trek principles. Similar to the German subsidiary, the UK subsidiary was briefed on the Star Trek initiative by headquarters and received extensive documentation. This was then followed by site visits by the consultancy firm involved in the early phase of the implementation process. At the UK site, the information on Star Trek was disseminated top-down through meetings and briefings, and several consultancy firms provided additional seminars and training modules on continuous improvement and lean manufacturing.

At UK Sub, transformation of the transferred knowledge was more superficial, and resulted primarily in a strong focus on performance indicators, such as service levels and stock levels. The reinterpretation of the Star Trek principles saw heavy involvement of external consultancy firms and predominantly manifested itself in ambitious target-setting and technical adaptations. For instance, standard operating procedures were redesigned and, on the initiative of the improvement manager of the paints division, work started on the creation of a ' $5 \mathrm{C}$ ' area based on the $5 \mathrm{~S}$ principles of workplace design. A consultancy firm set new production targets which, together with work schedules and performance indicators, were posted on notice boards on the shop floor. Operators followed training programmes to improve technical skills and multi-skilling. The training programmes also created awareness of the importance of a clean workplace and a "mental recognition of the importance of zero stock” (shift leader). Finally, employees were offered the possibility to create and volunteer for process improvement groups (PIGs) to encourage incremental improvements. 
However, whereas at German Sub the locally developed continuous improvement practices outlasted the Star Trek initiative, the local applications developed at the UK site failed to institutionalize, and the continuous improvement initiative was not sustained. For instance, the implementation of ' $5 \mathrm{C}$ ' areas was discontinued after the responsible consultancy firm and improvement manager left the site. Although one corner of the ground floor had been successfully transformed into a ' $5 \mathrm{C}$ ' area, the initiative did not produce the intended shop floor-wide shift in attitude. In the words of one operator: "if you spill there [the 5C area], you clean it up; but if you spill somewhere else, you just leave it”.

Along similar lines, the communication of targets and schedules through notice boards did little to motivate the operators, and even became a source of frustration. For example, workers on the shop floor indicated that the new externally-set filling speed was unrealistic, because "at that speed, paint would spill over the cans" (team leader). As an operator explained, "the target filling speed set by [the consultancy firm] is set at 40 tins per minute, whereas we can normally and reasonably do 22-28, perhaps 30.” Management nonetheless decided to leave the new target filling speed unchanged, with the result that on occasion “numbers were reported while the machine hadn’t even operated” (team leader).

In addition, many of the redesigned standard operating procedures (SOPs) were not applied and sustained in practice. Newly introduced SOPs were noted but not adhered to by operators. One operator explained that "they are brought in, people hear about it, but people tend to do it their own way", and that operators often "cut corners" to "get the job done”. Furthermore, SOPs were not communicated to new employees, even though new operators underwent extensive on-the-job training programmes. For example, when asked about SOPs, one of the new operators replied: "nobody has ever told me. You do what you see other people do." Similarly, another operator explained that "everybody has his own way, and people are trained differently”. 
Overall, the UK site showed limited transformation and application of the Star Trek initiative. Although many operators underwent some form of training in the light of HQ's Star Trek initiative, over half of the operators interviewed were unaware of Star Trek or its principles, and those who were aware often claimed to "do very little differently" (operator) compared with before. In all, in the words of the business unit's improvement manager: "If I had [to rate the extent to which the principles had been taken on board on] a scale from 1 to 10 , then I would say we are on 1 out of 10 ”.

\section{Social interaction at UK Sub}

A striking difference with the German site was the scope of actors involved in the acquisition, transformation, and application of the Star Trek principles, which remained largely in the hands of management and external consultants. External consultants suggested setting new production targets and using visual communication. Education on 'zero stock' was provided by an external institute, and new cleanliness and safety measures were imposed by external consultancy firms. Even the re-writing of SOPs saw little involvement of experienced operators. Some operators initiated and participated in process improvement groups, but these mainly focused on incremental improvements such as waste recycling in the canteen. Thus, although many operators participated in the externally organized training programmes, operators were, for the most part, not involved in translating the Star Trek principles at the UK site. As one operator commented, "Many of the suggestions made by [an external consultancy firm] had already been made by other operators ... but had not been acted on by management”.

In addition, social cohesion at the UK site was compartmentalized and characterized by strong hierarchical and moderate functional divides. Contrary to the German site, management was not involved with the shop floor and preferred communication via e-mail. 
In addition, management—which often socialized after work-was perceived to unconditionally side with shift supervisors (lower management) in the case of conflict, and preferred to distance itself from shop floor activities. Among operators, on the other hand, there was a strong culture of "not telling on your colleague" and a strong sense of distrust towards management. The strong degree of demarcation at the UK site severely hampered cross-hierarchical and cross-functional communication. Operators frequently complained about the lack of information from management, claiming: "We just don’t find out!" (operator), and expressed their frustration that suggestions from the shop floor were rarely taken on board.

Finally, interaction across functional and hierarchical groups was limited in scale and strongly tied to individual projects. Whereas at the German site interaction across hierarchical and functional levels had become commonplace, at the UK site, improvement initiatives were infrequent and limited in time. For instance, the involvement of consultants at the UK site was time-bound by nature, and produced piece-meal solutions such as setting over-ambitious targets or filling speeds. Similarly, process improvement groups (PIGs), which often involved actors from different functional areas, would dissolve when a problem had been resolved. This limited the ability of actors to engage in the transformation and application of the Star Trek principles beyond the specific task of the group. In addition, the PIGs were particularly vulnerable to time and resource shortages because they were not part of day-to-day work. They were often neglected when time and personnel shortages increased, which contributed to the fact that "the PIGs died before they started" (operator). 
The limited scope of social interaction at UK Sub reflected the absence of organizational conditions that would enable and encourage the participation of employees in transforming the Star Trek principles.

First, in contrast to German Sub, there was little sign of participatory leadership. Instead, management's approach to managing operations was distinctly hands-off, with operators suggesting that management had "no clear idea of what people are actually doing” and that "a lot of people can get away with things, work-wise". In addition, lower management was often perceived to rely on 'divide-and-conquer' tactics. For instance, management suggested that the more vocal blue shift was a problem-shift, even though performance indicators on the notice boards did not indicate any actual performance difference between the two shifts. Even headquarters characterized management at the UK site as "very traditional, political animals [and] not very good listeners" (European Improvement Manager).

A second constraint on widespread social interaction and involvement at UK Sub was the sharp structural demarcation between functional areas. Whereas at German Sub structural demarcations had gradually dissolved (following, for instance, the integration of maintenance and production), at UK Sub, strong structural demarcations continued to exist. For instance, maintenance and quality control operated independently from the shop floor, outside the shift-structure, and were physically removed from the production line. Even operators of different functional areas on the same shift had little need or opportunity for cross-functional cooperation on the job. This severely limited social interaction and the integration of maintenance and production know-how.

Finally, participation in the transformation of the Star Trek principles was not supported by an incentive system. Contrary to German Sub, at UK Sub there was no bonus system for meeting performance targets. Rather, for operators, the implementation of Star 
Trek resulted in a loss in shift payments, and the operators could not help but equate improvement with job loss.

\section{DISCUSSION}

What emerges from the findings is that the difference in learning outcomes at the two subsidiaries is inherently linked to differences in social interaction among the actors involved in learning activities (Table 5). At German Sub, where learning was extensive, actors from across the hierarchical range were involved in the transformation and application of the Star Trek initiative. There was a strong sense of social cohesion, and frequent—sustainedinteraction between employees on issues related to the transfer initiative. Instead, at UK Sub, the transfer initiative was not sustained. Here the transfer initiative saw little involvement of operators, and there was little social cohesion due to strong hierarchical and functional demarcation. In addition, cross-functional interaction was usually project-based and shortlived.

Table 5 about here

We draw on social perspectives on learning to shed light on why the different climates for social interaction translated into different learning outcomes (e.g., Gherardi and Nicolini, 2001; Elkjaer, 2005). Social perspectives on learning have recently received more attention in the literature on MNE knowledge processes (e.g. Hong et al., 2006a,b; Saka-Helmhout, 2007; Noorderhaven and Harzing, 2009). Such perspectives highlight that "learning does not take 
place solely or principally in the minds of individuals but rather stems from the participation of individuals in social activities" (Gherardi and Nicolini, 2001: 35). For organizational learning to be extensive, knowledge must be integrated locally: It must be acquired, transformed, and subsequently applied and sustained in actual practice, which inherently rests on social interaction. In other words, organizational learning is a social rather than an individual exercise, and therefore the locus of organizational learning is not the mind of the individual but rather the "participation patterns of individual members of organizations in which learning takes place” (Elkjaer, 2005: 43).

This suggests that the social interaction pattern at German Sub led to extensive learning because it enabled employees with diverse knowledge to engage in the transformation of the transfer content, and in the development of applications which were truly local and which workers perceived as their own. The case findings suggest that it is not merely the scale or extent of interaction but also its scope, or the diversity of interacting actors, that matters: At UK Sub, where participation in learning activities was limited to management and external consultants, the acquired knowledge underwent very little transformation. Applications of the acquired knowledge were relatively generic in nature, and remained close to the original Star Trek initiative. Instead, at German Sub, the participation of and interaction among a wide range of local actors resulted in the substantial transformation of the acquired knowledge, and in the development of applications that were both innovative and local. Thus, while knowledge stocks of the subsidiaries were comparable, at German Sub, the scale and scope of interaction enabled the participation of employees with diverse backgrounds. This, we theorize, explains the link between the observed differences in social interaction climates and learning outcomes.

The implication we draw for understanding the micro-macro dynamics of absorptive capacity is that organization level absorptive capacity is a function of both the motivation and 
the prior knowledge of employees who participate in learning activities (Cohen and Levinthal, 1990; Minbaeva et al., 2003), and of the social interaction patterns between these employees. While absorptive capacity at the individual level largely depends on individuals' knowledge structures (Cohen and Levinthal, 1990), absorptive capacity at the subsidiary level is not simply the sum of the knowledge and capabilities of individual employees. Successfully assimilating or accommodating external knowledge in new or existing schemata may lead individual employees to develop intuitive insights and innovations (cf. Todorova and Durisin, 2007), but the shared understanding and justification of new knowledge required for group problem solving and the joint development of local applications is produced in dialogue and social interaction (e.g., Crossan, Lane, and White, 1999; Yakhlef, 2010). Thus, the depth and diversity of knowledge of motivated employees only translates into absorptive capacity of the organizational unit if the scope of social interaction patterns surrounding knowledge activities also enables these employees to engage in the transformation of new knowledge.

Furthermore, while social cohesion impacts employees' motivation to engage in knowledge activities (Reagans and McEvily, 2003), the scale or extent of social interaction affects the extent of knowledge transformation and the development of local applications through, for instance, its impact on the quality of dialogue and the efficiency and pace with which shared local interpretations emerge (e.g. Carlile and Rebentisch, 2003; Crossan et al., 1999; Yeoh, 2009; Subramaniam and Youndt, 2005). Thus, the larger the scale and scope of social interaction surrounding learning-related activities, the more extensive the transformation that new knowledge can undergo, and the more extensive local applications arise $^{\mathrm{ii}}$. This leads us to propose the following: 
Proposition 1: Subsidiaries' absorptive capacity is positively related to the scale and scope of social interaction and the degree of cohesion among employees.

A key reason for the difference in social interaction patterns lies in the organizational conditions at both subsidiaries. At German Sub, local conditions such as participative leadership, the incentive system and low structural demarcation encouraged social interaction across hierarchical and functional divides, and thus facilitated the ability and willingness of employees to participate in the transformation of new knowledge. At UK Sub, however, such enabling organizational conditions were largely absent, which contributed to the lack of involvement of operators in the transformation of the Star Trek principles. In the context of absorptive capacity, research has predominantly focused on the organizational conditions that influence individual employee abilities and motivation. But similar to that "neither employees' ability nor motivation by themselves is sufficient to facilitate knowledge transfer” (Minbaeva et al., 2003: 596), the ability and motivation of individual employees only contributes to absorptive capacity at the subsidiary level if employees are also enabled and motivated to engage in the transformation of new knowledge. The case findings illustrate the influence of organizational conditions on subsidiaries' absorptive capacity where they enable and motivate social interaction and participation for the adoption, transformation and application of knowledge. This leads to the following proposition:

Proposition 2: The impact of organizational conditions that enable employees to engage in the transformation and application of new knowledge on subsidiaries' absorptive capacity is positively mediated by the scale and scope of social interaction.

\section{CONCLUSION}


While the importance of MNE knowledge processes is widely recognized (e.g., Kogut and Zander, 1993; Grant, 1996), we still know little about the role of local actors in these processes and how this is contingent on organizational conditions. Although the notion of absorptive capacity may partially address these issues, the absorptive capacity literature itself is unclear about the role of social interaction and is inattentive to how individual behaviour translates to absorptive capacity at the organizational level. This study makes several contributions to the advancement of both the IB knowledge transfer and absorptive capacity literature.

First, this study provides qualitative evidence of the importance of the participation patterns of local actors and of social dynamics in understanding subsidiary learning. In particular, the case findings suggest that different patterns of social interaction are related to the variation in subsidiaries' ability to adopt and apply new knowledge. Social interaction enables local actors to participate in the transformation of new knowledge at the local context and is therefore crucial in ensuring that individual absorptive capacity translates into absorptive capacity at the organizational level. Thus, while previous studies argue that internal social interaction patterns affect units' absorptive capacity indirectly, by facilitating knowledge sharing and promoting mutual understanding (e.g., Zahra and George, 2002; Todorova and Durisin, 2007), this study illustrates that social interaction constitutes a key link between the micro- and the macro-level, and is therefore a key requirement for organizational absorptive capacity.

Second, we illustrated that to understand how and why social interaction is enabled or constrained, it is crucial to consider organizational conditions. As the case findings suggest, the ability and motivation of individual employees only contributes to absorptive capacity at the subsidiary level if employees are also enabled and motivated by organizational conditions 
to engage in the transformation of knowledge. Thus, our study adds to a growing number of studies that call for a micro-perspective to understanding IB knowledge processes (e.g. Foss and Pedersen, 2004; Minbaeva et al., 2003) by suggesting how differences in certain organizational conditions, such as leadership style and structural demarcations, lead to differences in the absorptive capacity of MNE subsidiaries. Specifically, it supports and extends the notion that the impact of organizational conditions on organizational knowledge processes may be crucially mediated by social structure (Gooderham et al., 2011).

Third, our study illustrates how making better use of the notion of absorptive capacity to understand MNE knowledge processes also draws attention to the transformative aspect of knowledge transfer. As highlighted at the beginning of this paper, MNE knowledge research has thus far paid limited attention to the concurring change of both knowledge content and receiving context in the process of external knowledge integration. Successful transformation and application of the transferred knowledge does not merely imply change in knowledge content, but also change in practices, organizational conditions and, possibly, social interaction patterns of the receiving context. This, in turn, may impact the absorptive capacity of the receiving unit. Although we focused on just one knowledge transfer initiative, the change in organizational conditions at German Sub illustrates part of this recursive relationship between absorptive capacity and organizational learning (e.g., Cohen and Levinthal, 1990; Lane et al., 2006), where absorptive capacity is both an antecedent and consequent of learning rather than "a "thing" that is divorced of its context" (Lane et al., 2006: 858). As Sun and Anderson (2010) indicate, examining the relation between absorptive capacity and learning processes therefore holds considerable promise for enhancing our understanding of (subsidiary) learning outcomes.

The results of this study have several important implications for practitioners. As others have demonstrated, the ability of organizational units to acquire and apply new 
knowledge is positively related to learning (e.g., Lane, Salk and Lyles, 2001), innovativeness (e.g., Lichtenthaler, 2009; Tsai, 2001) and profitability (e.g., Bergh and Lim, 2008; Lichtenthaler, 2009; Tsai, 2001). This study illustrates that organizational conditions that facilitate and encourage social interaction among employees are key to organizational units’ absorptive capacity. As argued in both the absorptive capacity and the social learning literatures, new knowledge needs to be transformed at the local context in order to be accepted and successfully applied. Social interaction among employees, in terms of both scale (that is, the extent of social interaction) and scope (that is, diversity in employee backgrounds and roles), is a prerequisite for this. The acceptance and application of new knowledge can be actively encouraged and facilitated by practicing managers through, for instance, the adoption and promotion of a participatory leadership style, limiting of structural demarcations between functional areas, and the development of appropriate incentive systems, such as group bonus systems that reward collective rather than individual performance.

Our results also give rise to several new directions for further research. First, as the key strength of case-based research is in theory building rather than theory testing (e.g., Ghauri, 2004; Siggelkow, 2007), we encourage quantitative studies to examine the extent to which the case findings can be generalized. Second, although the organizational conditions identified in this study emerged as the most relevant to understanding the difference in social interaction patterns between the focal subsidiaries, it is likely that other factors, such as HRM practices, also impact social interaction (Leana and Van Buren, 1999). We, therefore, also encourage further work on the interplay between social interaction patterns and organizational conditions in order to gain more comprehensive insight into the contingencies that structure social interaction patterns. In addition, it would be wrong to assume that subsidiaries operate in a vacuum. A related question therefore is how the wider cultural and 
institutional environment in turn shapes such organizational contingency factors. Finally, although social perspectives on MNE knowledge processes are still relatively scarce, such studies are on the rise (e.g., Hong et al., 2006a; Saka-Helmhout, 2009). As this study illustrated, by highlighting how local actors and local conditions affect learning at the organizational level, social learning perspectives may prove valuable in future studies to better understand both the role of local actors and organizational conditions in MNE knowledge processes.

\section{REFERENCES}

Adler, P.S. and S.-W. Kwon (2002). 'Social Capital: Prospects for a New Concept', Academy of Management Review, 27, pp. 17-40.

Almeida, P. and A. Phene (2004). 'Subsidiaries and Knowledge Creation: The Influence of the MNC and Host Country on Innovation', Strategic Management Journal, 25, pp. 847-864.

Becker-Ritterspach, F. (2006). 'The Social Constitution of Knowledge Integration in MNEs: A Theoretical Framework', Journal of International Management, 12, pp. 358-377.

Bergh, D.D. and E. N.-K. Lim (2008). 'Learning How to Restructure: Absorptive Capacity and Improvisational Views of Restructuring Actions and Performance', Strategic Management Journal, 29, pp. 593-616. 
Björkman, I., W. Barner-Rasmussen, and L. Li (2004). 'Managing Knowledge Transfer in MNCs: The Impact of Headquarters Control Mechanisms', Journal of International Business Studies, 35, pp. 443-455.

Bower, G.H. and E.R. Hilgard (1981). Theories of Learning. Englewood Cliffs, NJ: PrenticeHall.

Carlile, P.R. (2002). ‘A Pragmatic View of Knowledge and Boundaries: Boundary Objects in New Product Development', Organization Science, 13, pp. 442-455.

Carlile, P.R. (2004). 'Transferring, Translating, and Transforming: An Integrative Framework for Managing Knowledge Across Boundaries', Organization Science, 15, pp. 555-568.

Carlile, P.R. and E.S. Rebentisch (2003) 'Into the Black Box: The Knowledge Transformation Cycle’, Management Science, 49, pp. 1180-1195.

Cohen, W.M. and D.A. Levinthal (1989). 'Innovation and Learning: The Two Faces of R\&D. Economic Journal', 99, pp. 569-596.

Cohen, W.M. and D.A. Levinthal (1990). 'Absorptive Capacity: A New Perspective on Learning and Innovation', Administrative Science Quarterly, 35, pp. 128-152.

Crossan, M.M., H.W. Lane, and R.E. White (1999). 'An Organizational Learning Framework: From Intuition to Institution’, Academy of Management Review, 24, 522-537. 
Dhanaraj, C., M.A. Lyles, H.K. Steensma, and L. Tihanyi (2004). 'Managing Tacit and Explicit Knowledge Transfer in IJVs: The Role of Relational Embeddedness and the Impact on Performance', Journal of International Business Studies, 35, pp. 428-442.

Eisenhardt, K.M. (1989). 'Building Theories from Case Study Research', Academy of Management Review, 14, pp. 532-550.

Eisenhardt, K.M. and M.E. Graebner (2007). 'Theory building from case studies: opportunities and challenges’, Academy of Management Journal, 50, pp. 25-32.

Elkjaer, B. (2005). 'Social Learning Theory: Learning as Participation in Social Processes'. In M. Easterby-Smith, \& M.A. Lyles (eds), The Blackwell Handbook of Organizational Learning and Knowledge Management, pp.38-53. Malden, MA: Blackwell Publishing.

Foss, N.J. (2007). ‘The Emerging Knowledge Governance Approach’, Organization, 14, pp. 29-52.

Foss, N.J. and T. Pedersen (2004). 'Organizing Knowledge Processes in the Multinational Corporation: An Introduction', Journal of International Business Studies, 35, pp. 340-349.

Ghauri, P. (2004). 'Designing and Conducting Case Studies in International Business Research'. In R. Marschan-Piekkari \& C. Welch (eds.), Handbook of Qualitative Research Methods for International Business, pp. 109-124. Cheltenham: Edward Elgar. 
Gherardi, S. and D. Nicolini (2001). 'The Sociological Foundations of Organizational Learning'. In M. Dierkes, A. Berthoin Antal, J. Child \& I. Nonaka (eds), Handbook of Organizational Learning \& Knowledge, pp. 35-60. New York: Oxford University Press.

Gooderham, P., D.B. Minbaeva and T. Pedersen (2011). 'Governance Mechanisms for the Promotion of Social Capital for Knowledge Transfer in Multinational Corporations', Journal of Management Studies, 48, pp. 123-150.

Grant, R.M. (1996). 'Toward a Knowledge-Based Theory of the Firm', Strategic Management Journal, 17, pp. 109-122.

Gupta, A.K. and V. Govindarajan (2000). 'Knowledge Flows within Multinational Corporations', Strategic Management Journal, 21, pp. 473-496.

Hansen, M.T. (1999). 'The Search-Transfer Problem: The Role of Weak Ties in Sharing Knowledge Across Organizational Subunits', Administrative Science Quarterly, 44, pp. 82111.

Hansen, M.T. and B. Løvås (2004). 'How Do Multinational Companies Leverage Technological Competencies? Moving From Single to Interdependent Explanations', Strategic Management Journal, 25, pp. 801-822.

Hong, J.F.L. and T.V. Nguyen (2009). 'Knowledge Embeddedness and the Transfer Mechanisms in Multinational Corporations', Journal of World Business, 44, pp. 347-356. 
Hong, J.F.L., M. Easterby-Smith, and R.S. Snell (2006a). 'Transferring Organizational Learning Systems to Japanese Subsidiaries in China’, Journal of Management Studies, 43, pp. 1027-1058.

Hong, J.F.L., R.S. Snell, and M. Easterby-Smith (2006b). Cross-Cultural Influences on Organizational Learning in MNCs: The Case of Japanese Companies in China'. Journal of International Management, 12, pp. 408-29.

Inkpen, A.C. and E.W.K. Tsang (2005). 'Social Capital, Networks, and Knowledge Transfer', Academy of Management Review, 30, pp. 146-165.

Jansen, J.J.P., F.A.J. Van den Bosch, and H.W. Volberda (2005). 'Managing Potential and Realized Absorptive Capacity: How Do Organizational Antecedents Matter?', Academy of Management Journal, 48, pp. 999-1015.

Kogut, B. and U. Zander (1993). 'Knowledge of the Firm and the Evolutionary Theory of the Multinational Corporation'. Journal of International Business Studies, $4^{\text {th }}$ Quarter, pp. 625645.

Lane, P.J. and M. Lubatkin (1998). 'Relative Absorptive Capacity and Organizational Learning', Strategic Management Journal, 19, pp. 461-477.

Lane, P.J., B.R. Koka, and S. Pathak (2006). 'The Reification of Absorptive Capacity: A Critical Review and Rejuvenation of the Construct', Academy of Management Review, 31, pp. 833-863. 
Lane, P.J., J.E. Salk, and M.A. Lyles (2001). 'Absorptive Capacity, Learning, and Performance in International Joint Ventures', Strategic Management Journal, 22, pp. 11391161.

Leana, C.R. and H.J. Van Buren (1999). 'Organizational Social Capital and Employment Practices', Academy of Management Review, 24, pp. 538-555.

Lichtenthaler, U. (2009). 'Absorptive Capacity, Environmental Turbulence, and the Complementarity of Organizational Learning Processes', Academy of Management Journal, 52, pp. 822-846.

Lindsay, P.H. and D.A. Norman (1977). Human Information Processing. Orlando, FL: Academic Press.

Miles, M.B. and A.M. Huberman (1994). Qualitative Data Analysis. Thousand Oaks, CA: Sage Publications.

Minbaeva, D., T. Pedersen, I. Björkman, C.F. Fey, and H.J. Park (2003). 'MNC Knowledge Transfer, Subsidiary Absorptive Capacity, and HRM', Journal of International Business Studies, 34, pp. 586-599.

Nahapiet, J. and S. Ghoshal (1998) 'Social Capital, Intellectual Capital and the Organizational Advantage', Academy of Management Review, 23, pp. 242-266. 
Noorderhaven, N.G. and A.W.K. Harzing (2009). 'Factors Influencing Knowledge Flows Within MNCs', Journal of International Business Studies, 40, pp. 509-526.

Pauwels, P.F.J. and P. Matthyssens (2004). 'The Architecture of Multiple Case Study Research in International Business'. In R. Marschan-Piekkari and C. Welch (eds.), Handbook of Qualitative Research Methods for International Business, pp. 125-143. Publishing, Cheltenham, UK: Edward Elgar.

Phene, A. and P. Almeida (2008). 'Innovation in Multinational Subsidiaries: The Role of Knowledge Assimilation and Subsidiary Capabilities', Journal of International Business Studies, 39, pp. 901-919.

Pisani, N. (2009). 'International Management Research: Investigating Its Recent Diffusion in Top Management Journals’, Journal of Management, 35, pp. 199-218.

Ragin, C.C. (1987). The Comparative Method: Moving Beyond Qualitative and Quantitative Strategies. Berkeley: University of California Press.

Reagans, R. and B. McEvily (2003). 'Network Structure and Knowledge Transfer: The Effects of Cohesion and Range', Administrative Science Quarterly, 48, pp. 240-267.

Saka-Helmhout, A. (2007). 'Unravelling Learning within Multinational Corporations', British Journal of Management, 18, pp. 294-310. 
Saka-Helmhout, A. (2009). 'Agency-Based View of Learning within the Multinational Corporation', Management Learning, 40, pp. 259-274.

Schilling, M.A. (2002). 'Technology Success and Failure in Winner-Take-All Markets: The Impact of Learning Orientation, Timing, and Network Externalities', Academy of Management Journal, 45, pp. 387-398.

Schulz, M. (2003). 'Pathways of Relevance: Exploring Inflows of Knowledge into Subunits of Multinational Corporations’, Organization Science, 4, pp. 440-459.

Siggelkow, N. (2007). 'Persuasion with Case Studies', Academy of Management Journal, 50, pp. 20-24.

Subramanian, M. and M.A. Youndt (2005). 'The Influence of Intellectual Capital on the Types of Innovative Capabilities’, Academy of Management Journal, 48, pp. 450-463.

Sun, P.Y.T. and M.H. Anderson (2010). 'An Examination of the Relationship Between Absorptive Capacity and Organizational Learning, and a Proposed Integration', International Journal of Management Reviews, 12, pp. 130-150.

Szulanski, G. (1996). 'Exploring Internal Stickiness: Impediments to the Transfer of Best Practice Within the Firm’, Strategic Management Journal, 17, pp. 27-43.

Szulanski, G. (2000). 'The Process of Knowledge Transfer: A Diachronic Analysis of Stickiness’, Organizational Behavior \& Human Decision Processes, 82, pp. 9-27. 
Todorova, G. and B. Durisin (2007). ‘Absorptive Capacity: Valuing a Reconceptualization’, Academy of Management Review, 32, pp. 774-786.

Tsai, W. (2001). 'Knowledge Transfer in Intraorganizational Networks: Effects of Network Position and Absorptive Capacity on Business Unit Innovation and Performance', Academy of Management Journal, 5, pp. 996-1004.

Tsai, W. (2002). 'Social Structure of “Coopetition” Within a Multiunit Organization: Coordination, Competition, and Intraorganizational Knowledge Sharing', Organization Science, 13, pp. 179-190.

Tsai, W. and S. Ghoshal (1998). 'Social Capital and Value Creation: The Role of Intrafirm Networks', Academy of Management Journal, 41, pp. 464-476.

Van den Bosch, F.A.J., H.W. Volberda, and M. de Boer (1999). 'Coevolution of Firm Absorptive Capacity and Knowledge Environment: Organizational Forms and Combinative Capabilities’, Organization Science, 10, pp.551-568.

Volberda, H.W., N.J. Foss and M.A. Lyles (2010). 'Absorbing the Concept of Absorptive Capacity: How to Realize its Potential in the Field', Organization Science, 21, pp. 931-951.

Yakhlef, A. (2010) 'The Three Facets of Knowledge: A Critique of the Practice-Based Learning Theory’, Research Policy, 39, pp. 39-46. 
Yeoh, P.-L. (2009). 'Realized and Potential Absorptive Capacity: Understanding their Antecedents and Performance in the Sourcing Context', Journal of Marketing Theory and Practice, 17, pp. 21-36.

Yli-Renko, H., E. Autio, and H.J. Sapienza (2001). 'Social Capital, Knowledge Acquisition, and Knowledge Exploitation in Young Technology-Based Firms', Strategic Management Journal, 22, pp. 587-613.

Zahra, S.A. and G. George (2002). 'Absorptive Capacity: A Review, Reconceptualization and Extension', Academy of Management Review, 27, pp. 185-203. 


\section{German subsidiary \\ UK subsidiary}

\section{Subsidiary characteristics}

Size

Acquired by

Dutch Chem

Activities

Skill levels

Technology

Context

\section{Knowledge \\ transfer \\ initiative}

Knowledge

content

Sending unit

Transfer channel

Learning

outcome
411 employees

1998

Wall paint and lacquer plant

Majority of workers semi-skilled, with an average of 18 years of employment in the subsidiary

Semi-automated mixing and filling units

High threat of plant closure and massive job loss, strong sense of competition between sites
324 employees

1994

Wall paint and lacquer plant

Majority of workers semi-skilled, with an average of 15 years of employment in the subsidiary

Semi-automated mixing and filling units

High threat of plant closure and massive job loss, strong sense of competition between sites
Continuous improvement principles

Headquarters

Documentation, personnel transfer, local workshops

Limited transformation and application of the transfer initiative application of the transfer initiative 
Table 2: Overview of informants and secondary data

\begin{tabular}{|c|c|c|c|}
\hline & Headquarters & German subsidiary & UK subsidiary \\
\hline \multirow[t]{6}{*}{ Informants } & $\begin{array}{l}\text { Supply Chain Europe } \\
\text { Director* }\end{array}$ & Site Manager* & Site Manager* \\
\hline & $\begin{array}{l}\text { European Improvement } \\
\text { Manager* }\end{array}$ & Plant Director* & Operations Director* \\
\hline & & 2 Factory Managers* & \\
\hline & & 2 Group Advisors* & 2 Shift Managers* \\
\hline & & HR Manager* & 3 Team leaders \\
\hline & & 10 Operators & 12 Operators \\
\hline \multirow[t]{5}{*}{ Documents } & Organization charts & Organization charts & Organization charts \\
\hline & $\begin{array}{l}\text { Star Trek Roadmap } \\
\text { (Outline of Star Trek } \\
\text { initiative: Vision, } \\
\text { Objectives, Targets, } \\
\text { Action Plans, } \\
\text { Improvements) }\end{array}$ & $\begin{array}{l}\text { Master Plan Continuous } \\
\text { Improvement Germany }\end{array}$ & $\begin{array}{l}\text { Master Plan Continuous } \\
\text { Improvement UK }\end{array}$ \\
\hline & $\begin{array}{l}\text { Star Trek strategy } \\
\text { paper (Production and } \\
\text { Logistics Strategy of } \\
\text { Division for Europe) }\end{array}$ & $\begin{array}{l}\text { Production Role Model } \\
\text { Cologne (behavioural } \\
\text { guidelines) }\end{array}$ & $\begin{array}{l}\text { Documentation on } \\
\text { Standard Operating } \\
\text { Procedures }\end{array}$ \\
\hline & & $\begin{array}{l}\text { Graphs on production } \\
\text { related indicators }\end{array}$ & $\begin{array}{l}\text { Graphs on production } \\
\text { related indicators }\end{array}$ \\
\hline & $\begin{array}{l}\text { Newsletters of Division } \\
\text { Production, Logistics } \\
\text { and Supply Chain }\end{array}$ & Newsletter of local site & \\
\hline
\end{tabular}


Table 3: Overview of knowledge absorption and learning outcomes at the two subsidiaries

\begin{tabular}{|c|c|c|c|c|c|}
\hline & \multicolumn{3}{|c|}{ Knowledge absorption } & \multirow[t]{2}{*}{ Learning outcome } & \multirow[t]{2}{*}{$\begin{array}{l}\text { Representative informant } \\
\text { quotes }\end{array}$} \\
\hline & $\begin{array}{l}\text { Acquired } \\
\text { knowledge }\end{array}$ & $\begin{array}{l}\text { Transformation of } \\
\text { acquired knowledge }\end{array}$ & Local applications & & \\
\hline UK Sub & $\begin{array}{l}\text { Continuous } \\
\text { improvement } \\
\text { systems and tools: } \\
\text { - Kaizen } \\
\text { - } \quad \text { Six Sigma } \\
\text { - } 5 \text { S } \\
\text { - Lean } \\
\quad \text { manufacturing }\end{array}$ & $\begin{array}{l}\text { Focus on key } \\
\text { performance } \\
\text { indicators } \\
\text { Focus on incremental } \\
\text { technical } \\
\text { improvements } \\
\text { Recognition of } \\
\text { importance of } \\
\text { cleanliness }\end{array}$ & $\begin{array}{l}\text { External target- } \\
\text { setting } \\
\text { Communication of } \\
\text { targets and schedules } \\
\text { Redesign of Standard } \\
\text { Operating Procedures } \\
\text { (SOPs) } \\
\text { Formation of process } \\
\text { improvement groups }\end{array}$ & 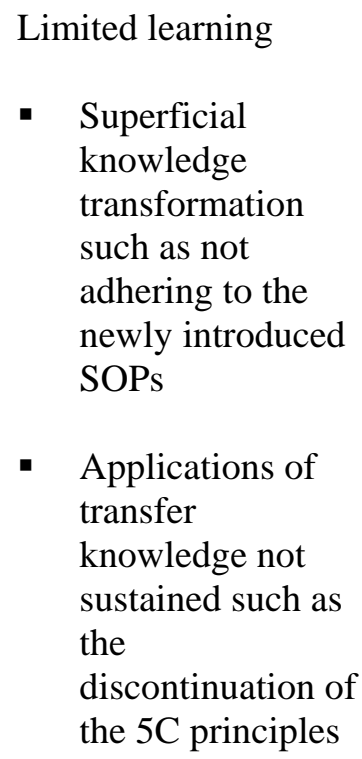 & $\begin{array}{l}\text { 'We can't produce that fast } \\
\text { because at that speed, paint } \\
\text { would spill over the cans' } \\
\text { 'There are graphs on the wall, but } \\
\text { I don't understand them' } \\
\text { 'they [SOPs] are brought in, } \\
\text { people hear about it, but people } \\
\text { tend to do it their own way' }\end{array}$ \\
\hline
\end{tabular}




\begin{tabular}{|c|c|c|c|c|c|}
\hline $\begin{array}{l}\text { German } \\
\text { Sub }\end{array}$ & $\begin{array}{l}\text { Continuous } \\
\text { improvement } \\
\text { systems and tools: } \\
\text { - Kaizen } \\
\text { - Six Sigma } \\
\text { - } 5 \text { S Lean } \\
\text { manufacturing }\end{array}$ & $\begin{array}{l}\text { Shift in focus towards } \\
\text { behavioural aspects } \\
\text { of continuous } \\
\text { improvement } \\
\text { Selective adoption of } \\
\text { tools and systems } \\
\text { Adaptation of } \\
\text { adopted tools and } \\
\text { systems } \\
\text { Relabeling of Star } \\
\text { Trek to enhance the } \\
\text { meaning of the } \\
\text { continuous } \\
\text { improvement } \\
\text { programme for local } \\
\text { workers }\end{array}$ & $\begin{array}{l}\text { Efforts to create a } \\
\text { continuous } \\
\text { improvement culture } \\
\text { Formulation of new } \\
\text { behavioural standards } \\
\text { Incremental } \\
\text { adaptations in } \\
\text { practices and routines } \\
\text { to improve } \\
\text { production, } \\
\text { cleanliness and safety }\end{array}$ & $\begin{array}{ll}\text { Extensive learning } \\
\text { - } \\
\text { Extensive } \\
\text { knowledge } \\
\text { transformation }\end{array}$ & $\begin{array}{l}\text { 'They have translated our whole } \\
\text { Star Trek program into their own } \\
\text { program for the Cologne site, } \\
\text { with a vision, with how they } \\
\text { operate, what they do, how they } \\
\text { measure the success' } \\
\text { 'If a production run fails, costing } \\
\text { about } 30.000 \text { to } 40.000 \text { Euros, } \\
\text { workers are not punished } \\
\text { anymore. Instead, they enter the } \\
\text { office without hesitation and } \\
\text { admit something has gone } \\
\text { wrong.' }\end{array}$ \\
\hline
\end{tabular}


Table 4: Social interaction patterns and organizational conditions

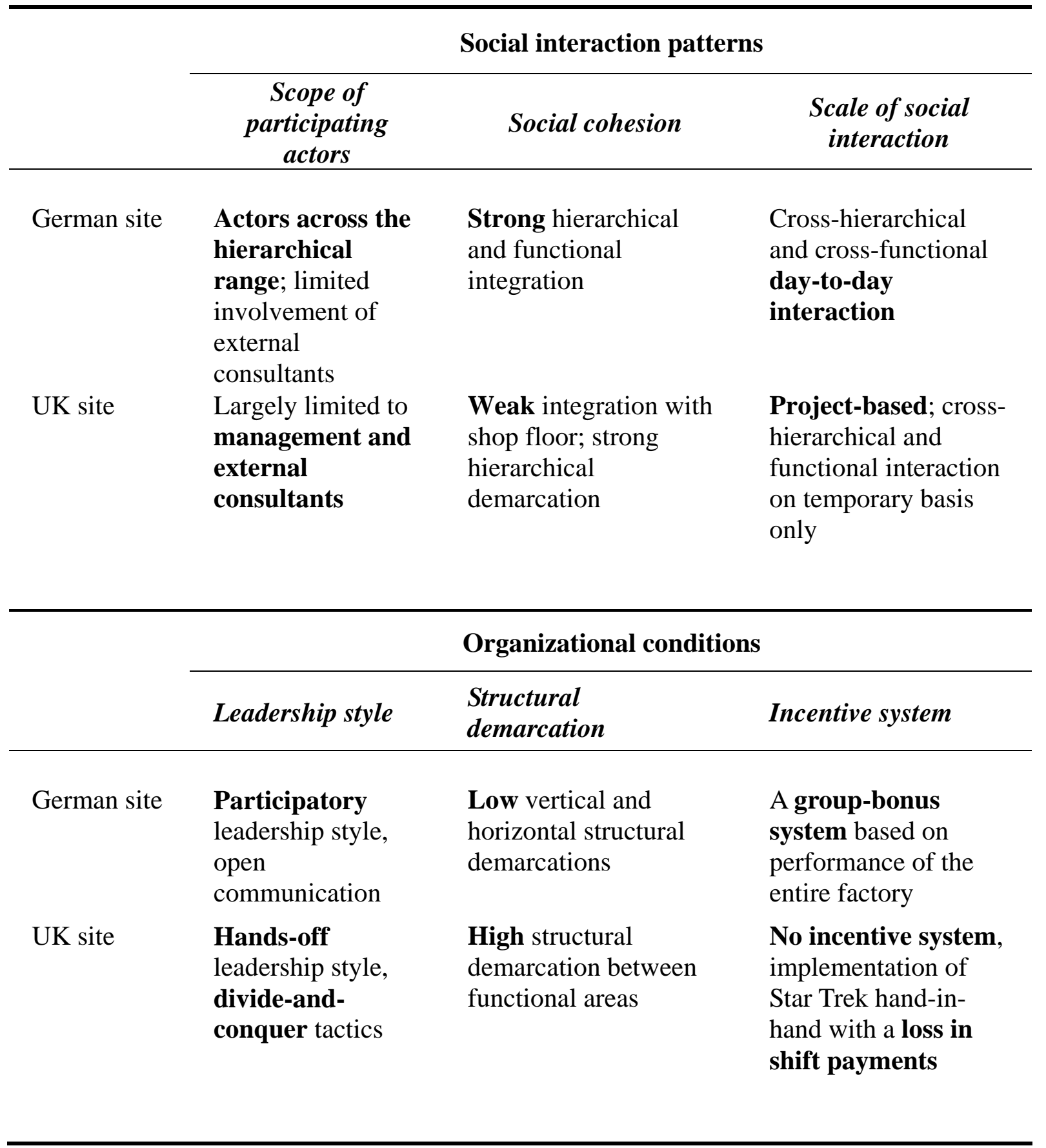


Table 5: Summary of findings

\begin{tabular}{llll}
\hline Learning outcome & Social interaction & \multicolumn{1}{c}{$\begin{array}{c}\text { Organizational } \\
\text { conditions }\end{array}$} \\
\hline $\begin{array}{l}\text { German } \\
\text { site }\end{array}$ & $\begin{array}{l}\text { Extensive } \\
\text { transformation and } \\
\text { sustained application } \\
\text { of transfer knowledge }\end{array}$ & $\begin{array}{l}\text { Extensive in scale and } \\
\text { scope, strong cohesion }\end{array}$ & $\begin{array}{l}\text { Supportive organizational } \\
\text { conditions that enabled and } \\
\text { encouraged participation }\end{array}$ \\
UK site & $\begin{array}{l}\text { Limited } \\
\text { transformation and } \\
\text { limited sustained } \\
\text { application of transfer } \\
\text { knowledge }\end{array}$ & $\begin{array}{l}\text { Limited in scale, scope } \\
\text { and cohesion }\end{array}$ & $\begin{array}{l}\text { Unsupportive } \\
\text { organizational conditions } \\
\text { that hindered participation }\end{array}$ \\
\hline
\end{tabular}


APPENDIX: Illustrative list of codes

\begin{tabular}{|c|c|c|c|}
\hline $\begin{array}{l}\text { Main } \\
\text { categories }\end{array}$ & Sub-categories & Illustrations German Sub & Illustrations UK Sub \\
\hline \multirow[t]{3}{*}{$\begin{array}{l}\text { Absorptive } \\
\text { capacity }\end{array}$} & Acquisition & $\begin{array}{l}\text { "We had some problems in our German operation to be } \\
\text { profitable in the market, so there was a lot of pressure } \\
\text { on the German site to improve." } \\
\text { "It was to believe in something or to leave the } \\
\text { company. That is where it started with me [the plant } \\
\text { manager]. And then I tried to get some people who } \\
\text { wanted to start the same dream." }\end{array}$ & $\begin{array}{l}\text { "We have been putting a lot of effort in conveying the } \\
\text { message to all levels of the organisation, I think we } \\
\text { have spent hell of a lot of time and effort in conveying } \\
\text { the message that basically this is a good thing, } \\
\text { because we are not going to close your site down. You } \\
\text { will get a chance. If we do the right steps in the right } \\
\text { order and we show results, then we are away, we are } \\
\text { flying. That message has been communicated top } \\
\text { down pretty good I think." }\end{array}$ \\
\hline & Transformation & $\begin{array}{l}\text { "[The people at German Sub] have translated our } \\
\text { whole Star Trek program into their own program for } \\
\text { the Cologne site, with a vision, with how they operate, } \\
\text { what they do, how they measure the success" } \\
\text { "I would say that 'Star Trek' has no meaning for the } \\
\text { people. I know that other sites did that differently but } \\
\text { we very deliberately took the decision not to sell it } \\
\text { under the label Star Trek." }\end{array}$ & $\begin{array}{l}\text { “There is a lot from headquarters that is relevant but we } \\
\text { are asked further questions like 'Where do you see } \\
\text { yourself in the future? What is your local vision?' We } \\
\text { don't know how these translate to the operational } \\
\text { level.” } \\
\text { "Either principles have not been translated into shop } \\
\text { floor objectives or there is a fear factor at first-line } \\
\text { and middle management levels.” }\end{array}$ \\
\hline & Application & $\begin{array}{l}\text { “Earlier, if a change in the recipe was required because } \\
\text { it didn't work ... it was difficult to discuss these } \\
\text { changes with the laboratory. They didn’t care much or } \\
\text { were not very responsive to the demands and } \\
\text { requirements of producing a recipe that works well in }\end{array}$ & $\begin{array}{l}\text { "We have made a few demonstrations, improvement } \\
\text { projects here and there. But it has not become a way } \\
\text { of life" } \\
\text { "[New standard operating procedures] are brought in, } \\
\text { people hear about it, but people tend to do it their own }\end{array}$ \\
\hline
\end{tabular}


the laboratory to the large scale of production. This has changed fundamentally"

"The resolutions of problems and changes to the process have gotten much faster and more flexible" way"

"We can't produce that fast [at the newly imposed target filling speed] because at that speed, paint would spill over the cans"

\section{Social} interaction Participating actors

patterns
"[Some of the new initiatives] come from the leaderlevel in filling and in production, but for the most part it comes from the people working on the machines who work with them day-in day-out with them and say 'Listen, I have a problem here can't we do this or that'. Most of the time it comes from the shop floor."

"In my view the role model has been developed out of the midst of the site."

Social cohesion "that's the nice thing, now they all help each other. Earlier the colouring guy wore the colouring hat and would say 'why should I carry the barrel?' "”

"For me it was important, when you were in the past in the factory building: here was the mixing process, here the colouring process and here the filling. These were three levels. When the one pushed the barrel wagon, the barrel, the other one did this and a third one did that and they didn't help each other much.”

Strength and "I now call [a group advisor] and say 'Listen, I have a persistence of big problem downstairs at the robot-palletizer, can social you please send someone there?' and he also sees or interaction
"Many of the suggestions made by [the external consultancy firm] had already been made by other operators ... but had not been acted on by management"

"I was involved in rewriting [standard operating procedures] at [my previous job], where they use the exact same machine as well and where I used to be a training officer, but I am not involved in the rewriting here.”

"Higher management should have an independent position [but] they unconditionally side with lower management ... because lower and higher management are friends; [they] hang out together" "We call them [names], they call us"

"Most of the time we hear things by word of mouth rather than through briefings or notes. I'm briefed about two times a year, if I'm lucky." 
that's what we have achieved."

\section{Organizational Structural} conditions
"Just an example, the reorganization of the maintenance department. ... This reorganization is also a change of pattern. We used [some] out of the [original] team, the rest we split over the factory and integrated into the process. That brought instability because the factory leader was all of a sudden responsible for maintenance, and the maintenance people all of a sudden, when there was no ... down time or whatever, they were also expected to ... to produce the product."

Leadership style “The most important thing is that you take people on board; if you don't do that you don't even have to start ... . you have to listen to them , you have to talk to them and you have to give feedback be it positive or negative.”

Incentive system
"People perceive these things [bonuses] and are now really capable to select themselves what are the things that maybe hurt me and which are the things we can say 'OK, let's not make a fuss over it.'”

"They were also integrated into the group-bonus system. They get their fair share if performance is alright and that has its Eigendynamic [own dynamics]. All discussion aside that money is just a short term motivation; but it motivates the people quite a lot."
"The PIGs [cross-functional process improvement groups] died before they started"

“[The new shift manager] doesn't really know what's going on, because [he] came from maintenance rather than from the shop floor.”

"[Management] should listen more, because currently management does not listen to suggestions and operatives are not asked about issues.”

"I like my new job, especially the medical care, pension care, health and safety. But if you work here for a long time, you don't see the benefits anymore and just become sceptical."

"[The knowledge transfer initiative] has also meant a loss in shift payments. This was a lot of concern to the operators." 
${ }^{\mathrm{i}}$ A valid question is how the link between absorptive capacity and organizational learning should be conceptualized. As Sun and Anderson (2010) note, while some authors view absorptive capacity as an antecedent to organizational learning (e.g., Reagans and McEvily, 2000: Szulanski, 1996), others see organizational learning as the antecedent (e.g., Schilling, 2002), and still others view the two concepts as having a recursive relationship (e.g., Cohen and Levinthal, 1990; Lane and Lubatkin, 1998; Tsai, 2001). In this paper, we concur with the (recursive) view that a subsidiary's capacity to acquire and utilize externally held knowledge is an antecedent to subsidiary learning, and in turn see subsidiaries' absorptive capacity as generated by "sociopsychological learning processes" (Sun and Anderson, 2010: 141) that are conditional on organizational conditions (Lane et al., 2006).

${ }^{\text {ii }}$ It is likely that the effect of social interaction patterns on absorptive capacity is subject to diminishing returns due to, for instance, increased complexity and conflict as interaction becomes more extensive (e.g., Carlile, 2002; Carlile and Rebentisch, 2003). 